The nearer the form and habits of man in his most primitive stage resembled those of the apes, the more in all probability would his habitat or range have been identical with theirs. Therefore an examination of miocene or early pliocene deposits along this line and its diverging branches would scarcely be unattended with success in producing many fossil remains of very primitive or Simian man.

I trust I have said enough to indicate the direction which inquiry ought to take as far as present evidence goes, and I hope that a gigantic combined effort may ere long be made by all naturalists and all lovers of truth to attempt in a downright earnest manner the solution of this great question of the origin of man.

W. S. DUNCAN

\section{The Stone in the Nest of the Swallow}

Would any of your readers be hind enough to give me some information about the origin of the fable to which Longfellow refers in the following passage of his "Evangeline," Part I., at the end :-

" Oft in the barns they climbed to the populous nests on the rafters,

Seeking with eager eyes that wondrous stone, which the swallow

Brings from the shcre of the sea to restore the sight of its fledglings ;

Leiden, March Ig

P. P. C. HOEK

\section{Carnivorous Wasps}

Sir David Wedderburn's inquiry (Nature, vol. xxi. p. 417) reminds me of my experience on this subject. Many years ago I was examining an apple-tree, when a wasp alighted on a leaf which formed a caterpillar's nest neatly rolled up. The wasp examined both ends, and finding them closed, it soon clipped a hole in the leaf at one end of the nest about one-eighth of an inch in diameter. It then went to the other end and made a noise which frightened the caterpillar, which came rushing out at the hole. It was immediately seized by the wasp, who, finding it too large to carry off at once, cut it in two and went off with his ame. I waited a little, and saw the wasp come back for the other half, with which it also flew away.

After witnessing such evidence of intelligence I have had a great respect for wasps, and gave orders to my gardeners never to destroy one.

I gained some further evidence of their carnivorous taste when I once took my children to Switzerland for a holiday, and on a butterfly hunting expedition. We had spread out the day's find in the Evening, and next morning I placed the boards in the sun to dry. On looking at them sowe hours later I found nearly all the bodies gone, only the thorax and wings left; and while examining them a wasp alighted on the board, and I soon proved that he was the culprit.

I have no doubt that wasps are most serviceable to gardeners by destroying caterpillars.

R. S. NEWALI

March 2I

\section{Intellect in Brutes}

Some time since $I$ observed the following conduct of two spiders, which will show how they sometimes overcome diffculties in the way of capturing their prey. A rather large housesfider had its web in the comer of a room, and during the summer it feasted upon the insects that were unlucky enough to be caught. One evening I noticed a large dipterous insect strike the web ; the spider darted out and succeeded in fastening on foot of the fly. The spider then l ept running back and forth, attaching a thread to a wing, then to a leg, which was soon broken by the violent efforts of the fly to release itself. The spider worked without ceasing for over half an hour to secure its victim ; it then quitted operations, and retired to a distant corner of its web. After seeming to reflect for a $\mathrm{u}$ hile what was best to do, it left the web, went up the wall eight or ten inches distant, ard entered a crack in the ceiling. I supposed at the time that the spider had been injured in the scuffle, but what was my surprise after a few moments to see the spider coming back, and close behind another followed; the two went on the web near the centre, and stopped side by side, apparently consulting as to the best mode of attack. Then at the same instant both spiders darted upon the insect, one towaros the head, the other towards the tail. So rapid were their movenien's I conld hardly follow them. In a short time the insect was : ecurely fastened. Both spiders then returned to the ctntre of the web. Soon after the friendly spider went to the crack in the ceiling, while the other enjoyed the feast alone.

North Manchester, Indiana, U.S., February 25

A. $M$.

\section{Diatoms in the London Clay}

Your correspondent, Mr. W. H. Shrubsole, inquires where sections may be seen in the lower part of the London clay. He will find a good exposure in a brick-yard, half a mile south-west of Roydon Station on the Great Eastern Railway; in another at Hadham Ford, on the Buntingford branch line, and several in the brick-fields near Bishop Stortford. In all these sections the lowest part of the London clay may be seen, resting upon sands, or loams, of the Reading series. Upon direct application, or otherwise, I shall be happy to supply Mr. Shrubsole with further information.

Granville House, Finsbury Park, N.

W. H. Penning

\section{VISUALISED NUMERALS}

SINCE I addressed a preliminary memoir to you on this subject, ${ }^{1}$ so much curious matter has reached me that I trust you will permit me to state my views afresh, and to deduce some inferences. Many of my readers do not and cannot visualise, and few have the habit in a pronounced degree. I must, however, beg them not to consider their own minds as identical with those of every other sane and healthy person. Psychologists ought to inquire into the mental habits of other men with as little prejudice as if they were inquiring into those of animals of different species to their own, and should be prepared to find much in many cases that is quite unlike their own personal experience.

Persons who have the tendency to use mental pictures as the symbols with which they carry on their processes of thought, do so especially in the case of numerals. Thus, when they think of "six," the figure " 6 " arises before the mind's eye more readily and vividly than the sound "six" echoes in their mind's ear, or than any other perception of that numeral manifests itself. Now the peculiarity that I accidentally found out is this, that about one out of every thirty males, or fifteen females, not only visualise their numerals in this way, but also invariably assign to each of them a definite place in their mental field of view, where it seems to have a home. Thus 6 may always lie low down to the left, 7 may be found a little higher and more to the front, and so on. It follows that whenever these persons think of a series of numbers, as I, 2, 3, 4, 5, \&c., they always appear to the mind's eye as ranged in a definite pattern or "form." This form is stated in all cases to have been in existence at the farthest period to which recollection goes back, though in many cases it has insensibly grown until it included the higher numbers and even negative values. it is usually of a rambling irregular shape, and though constant for the same person, it differs very greatly in different persons. It may consist of a row or rows of faintly marked figures, suspended in the air or lying on a hazy ground, and when the mental eye travels along the row, each as it is looked at in succession becomes for the moment vivid. Or it may consist of a faint line with nothing on it, along which the eye is wont to travel unti? it reaches the place where the figure it wants is known to reside, and then the figure starts into sight. Or it may be a haze penetrated by faint lines. Cr there may be no figures at all in the line, but only dots denoting position. The planes on which the forms lie slope in some cases up to the heavens, in others down to an immeasurable abyss. They of ten start a little below the level of the eye and rise gently upwards, reminding one of what the appearance of objects on a table would be to a child whose head hardly overtopped it. All these forms can be drawn in a way more or less satisfactory to those who see them, and I have now received nearly eighty drawings, in about NATURE, vo!. $x^{\top}$. p. 252. 